\title{
農業経営におけるCSR 会計の構築に関する研究
}

\author{
大前ひとみ 1$) *$ ・古塚 秀夫 ${ }^{2)}$
}

\section{Creating a CSR Accounting Table for Agricultural Management}

\author{
Hitomi Omae ${ }^{1) *} \&$ Hideo Furutsuka ${ }^{2)}$
}

This study creates a CSR accounting table for farmers in three steps. First, the study describes the characteristics of general CSR accounting. Then, production data are used to create a CSR accounting table. Finally, the table is employed to demonstrate the CSR analysis method. These three steps produced three main results. (1) Most CSR キーワード：農業経営, CSR 会計, 社会的責任, 地域還元

\section{1. はじめに}

近年，企業の不祥事が相次いでいることから，社 会ではCSR（企業の社会的責任）への注目が高まっ ている. CSR とは，従来の経済的側面の活動だけで なく，社会・環境の側面も含んだ企業活動のことで ある.この CSR の広がりに伴って，多くの一般企業 が CSR 報告書を発行し，一部の企業が CSR 会計を 報告している。農業に执いても，次のような理由に よって CSRを行ら必要性が高まっている。すなわ ち，食の安全への消費者意識が高いこと，女性労働 が家事と農作業を負担することにより過重になって いること，家族労賃の適正な評価と支払いが必要に なっていること，農薬と化学肥料の過度な使用によ り環境が污染されていること，などである。しかし， 農業経営に拈いて CSR 会計は未だに構築されてい ない。

そこで，本研究では農業経営における CSR 会計の 構築を目的としている. この目的を達成するために, 第 1 に，一般企業が報告している CSR 活動， CSR accounting tables are found to reveal forms of added value at high rates of reliability. (2) This enables the creation of CSR accounting table showing forms of added value for agricultural management and (3) the introduction of an analysis method for CSR accounting tables using values such as "pass-on amount for area", and "average of pass-on for area."
会計の特徵を明らかにする ${ }^{1}$. 第 2 に，鳥取市にあ る農事組合法人 Y 生産組合（以下 Y 生産組合とい ら，2012 年度，2013 年度）を事例として，生産履 歴を利用した農業経営に打村る CSR 会計について検 討する，第 3 に，農業経営に打忷 CSR 会計につい て分析方法を検討する.

\section{2. 既往の研究成果}

\section{（1）一般企業に関する研究成果}

一般企業に関する研究成果として，倍（2008） は，一般企業が報告している CSR 会計を次の 5 つに 類型区分している. 寸なわち，その 1 として，付加 価值分配型である.この類型は，「付加価値をステー クホルダーに対してどのよらに分配したか」（倍, 2008 : p. 148）を示す方式である. その 2 として, 収入支出対比型である。この類型は「損益データを 収入と支出に区分し，その内訳とステークホルダー との関係を明らかにする」（倍，2008：p. 148）方式 である。その 3 として，CSR 関連コスト主体型であ

\footnotetext{
1) 鳥取大学大学院農学研究科; Graduate School of Agriculture, Tottori University

2) 鳥取大学農学部; Faculty of Agriculture, Tottori University

*E-mail: umeko30@gmail.com 
る.この類型は，CSR 活動に要した費用を開示する 万式である。 その 4 として，CSR 関連効果対比型で ある。これは，CSR 関連コスト主体型に貨幣価値以 外の物量ベースや文章を用いた効果の側面を加えた ものである. その 5 として，総合的 CSR 関連効果対 比型である. これは，CSR 関連効果対比型の効果の 側面に貨幣価值を加えて効果を示す方式である。本 研究では, 付加価值分配型と収入支出対比型をまと めて付加価值型，CSR 関連コスト主体型と CSR 関 連効果対比型, 総合的 CSR 関連効果対比型の 3 つを まとめて CSR 関連コスト型と呼び，この類型に基ら゙ いて研究を行ら.

\section{（2）農業経営に関する研究成果}

第 1 に，佐々木（2008）は，社会的責任を社会的 期待と応答と捉え，農業経営はその応答により意思 決定を行らものであり，そのことを「応答的意思決 定」と呼んでいる．この「応答的意思決定」を会計 表示するために新たに必要となる勘定が「応答的純 資産勘定（仮称）」である．図 1 に応答的純資産勘定 を含んだ一連の会計報告を示している。これは，今 までの現金収支計算書，貸借対照表，損益計算書に 応答的純資産計算書を組み込むといらことである。 この応答的純資産計算書は CSR 活動の収支を表し たものである.つまり, 貸方は CSR 活動の遂行に伴 う純資産の増加を，借方は純資産の減少を意味して いる。今までは，損益計算書の借方にある当期純利 益が貸借対照表に組み込まれていたが，この新会計 では，当期純利益は応答的純資産計算書に組み込ま れて，CSR 活動の遂行に伴ら収支の末，算出される

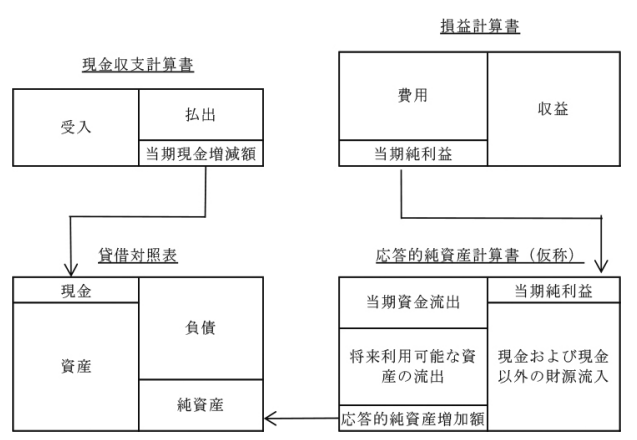

図 1. 社会的責任を組み込んだ経営の財務諸表のイ メージ

出所 : 佐々木 (2008) p. 408 図 2 を引用.
応答的純資産増加額が貸借対照表に組み込まれる。 この研究では，社会的責任を組み込むために新たな 勘定科目と計算書が必要となる。しかし，小規模零 細な農業経営にとって，勘定科目の増加と新しい計 算書の作成は大きな負担になる。したがって，本研 究では, 既存の勘定科目と財務諸表から CSR 会計を 構築することを考えている.

第 2 に，香川他（2008）によると, トリプルボト ムラインの概念から CSR は, 経済的パフォーマン ス・環境パフォーマンス・社会的パフォーマンスの 3つに分けることができる. そして, 経済的パフォ ーマンスとしては付加価値計算書を, 環境パフォー マンスとしては環境会計や環境活動報告書を, 社会 的パフォーマンスとしては労働慣行・人権・社会・ 製品責任について情報開示すべきであるとしている. この経済的パフォーマンスに農業経営に打ける付加 価値計算書があげられる．本来の付加価值は，「企業 の最終的な売上高から原材料など外部から仕入れた 物財費を差し引いた額として計算される」（香川他, 2008 ：p. 418）が，CSR 会計に打ける付加価值計算 書では誰に対する支出で誰による収入なのかを明確 に情報開示する必要がある，そのために，売上高や 労働費などの項目に，「地元地域」などと内訳を示す 必要がある. 特に家族労賃は,「自家労働を公正に評 価していることや，税務上の会計操作を行っていな いことを明示することにつながる」（香川他，2008： p. 419）としている。 また，農業経営に拈いては， 「国土の占有的利用を行っている事実から, 土地純収 益等の指標を組み込む必要がある」(香川他, 2008 : p. 419）としている. 本研究では, 小作地について 支払地代を付加価値の分配額として計上する.

\section{3. 一般企業における CSR 活動の現状 （1）CSR 報告書等 2}

「エコほっとライン」 ${ }^{3}$ にCSR 報告書等を掲載し ている一般企業 505 社について 2012 年度を対象に CSR 報告書等の内容を検討する.すなわち，第 1 に，GRI ガイドラインの実施についてである，GRI (Global Reporting Initiative) は，オランダに本部を 沶く非営利団体であり，全世界で使用可能な持続可 能性報告のガイドラインを作成・普及している. こ の GRI ガイドラインは大きく 4 つの組織情報（戦略 
拈よび分析, 組織のプロフィール, 報告要素, ガバ ナンス・コミットメント）と6つの社会的パフォー マンス（経済，環境，労働，人権，社会，製品）に 分けられており，CSR 報告書にはこれらの項目につ いて揭載すべきとしている，CSR 会計においても， この項目に着目して報告する必要がある。この GRI ガイドラインの指標と業種別開示率を示したのが表 1 である. 調査した企業 505 社のらち, GRI ガイド ライン対照表を記載していたのは，152 社であった. 表 1 の值は, 開示企業数を各業種の企業数で割った ものである、変動係数の值が大きいほど業種間の格 差が大きいといえる. 表 1 から組織情報（上述（） 内参照）では平均開示率が高い. 特に「戦略および
分析」と「組織のプロフィール」では平均開示率が $90 \%$ 以上と高く, しかも, 変動係数が小さい. この ことから，これらの項目は汪とんどの企業で開示さ れているといえる。それに対して，社会的パフォー マンス（上述（）内参照）については，開示があ まりされて扔らず，特に「人権」「社会」「製品」で は平均開示率が約 $30 \%$ と低く, 変動係数が大きいこ とから, これらの項目は開示率が相対的に低く, し かも業種間で開示の有無に格差があるといえる.

第 2 に, ISO260004 の開示率を表 2 に示している. 表 2 の見方は表 1 と同じである. ただし，ISO26000 対照表を記載している企業が 25 社と少なかったた め 5 に, 表 1 では記載している業種が表 2 では記載

表 1. 業種別 GRI ガイドライン開示率

単位: $\%$, 社

\begin{tabular}{|c|c|c|c|c|c|c|c|c|c|c|c|}
\hline 業種 指標 & $\begin{array}{l}\text { 戦略及び } \\
\text { 分析 }\end{array}$ & $\begin{array}{c}\text { 組織のプロ } \\
\text { フィール }\end{array}$ & 報告要素 & $\begin{array}{l}\text { ガバナンス, } \\
\text { コミットメント }\end{array}$ & 経済 & 環境 & 労働 & 人権 & 社会 & 製品 & 企業数 \\
\hline 建築業・農林 & 100.0 & 96.7 & 80.8 & 80.4 & 48.1 & 61.1 & 50.0 & 31.5 & 39.6 & 46.3 & 6 \\
\hline 食料品・医薬品 & $\underline{96.7}$ & 94.3 & 79.0 & $\underline{80.2}$ & $\underline{36.3}$ & 60.2 & $\underline{48.3}$ & $\underline{21.5}$ & 31.7 & 37.4 & 30 \\
\hline 石油・ガラス & 100.0 & 96.0 & 81.5 & 88.8 & $\underline{37.8}$ & 62.7 & 57.9 & 34.4 & 50.0 & 46.7 & 10 \\
\hline 鉄鋼・金属 & 100.0 & 93.3 & 81.2 & 85.0 & 53.1 & 61.5 & $\underline{42.9}$ & $\underline{23.5}$ & 40.3 & $\underline{35.8}$ & 9 \\
\hline 機械・電気製品 & 98.3 & 94.3 & 79.7 & 83.5 & 45.6 & 64.6 & 51.0 & 40.4 & 36.7 & 40.4 & 30 \\
\hline 輸送用・精密機器 & $\underline{97.4}$ & $\underline{90.5}$ & $\underline{70.4}$ & $\underline{72.1}$ & $\underline{36.8}$ & 65.8 & 51.5 & $\underline{27.5}$ & $\underline{27.0}$ & $\underline{28.1}$ & 19 \\
\hline 卸売業・金融業 & $\underline{96.2}$ & $\underline{92.3}$ & 79.3 & 91.4 & 46.2 & $\underline{51.0}$ & $\underline{42.3}$ & 30.8 & $\underline{27.9}$ & $\underline{27.4}$ & 13 \\
\hline 証券・保険 & 100.0 & $\underline{92.5}$ & $\underline{76.9}$ & 84.8 & $\underline{35.2}$ & $\underline{39.2}$ & $\underline{46.4}$ & $\underline{15.7}$ & $\underline{28.1}$ & $\underline{30.6}$ & 12 \\
\hline 不動産・運輸業 & $\underline{91.7}$ & $\underline{91.7}$ & $\underline{75.6}$ & $\underline{71.6}$ & 42.6 & $\underline{56.7}$ & 54.8 & 31.5 & $\underline{31.3}$ & $\underline{35.2}$ & 6 \\
\hline 通信業・電気・ガス & 100.0 & $\underline{91.2}$ & $\underline{70.1}$ & $\underline{81.3}$ & $\underline{39.2}$ & 59.0 & 52.5 & $\underline{19.0}$ & $\underline{34.6}$ & $\underline{35.9}$ & 17 \\
\hline 総合 $($ 平均 $)$ & 98.0 & 93.3 & 78.1 & 81.9 & 42.1 & 58.2 & 49.8 & 27.6 & 34.7 & 36.4 & 152 \\
\hline 標準偏差 & 2.6 & 1.9 & 4.0 & 6.1 & 5.7 & 7.5 & 4.7 & 7.2 & 6.8 & 6.4 & - \\
\hline 変動係数 & 2.6 & 2.1 & 5.2 & 7.4 & 13.5 & 12.8 & 9.4 & 26.2 & 19.6 & 17.6 & - \\
\hline
\end{tabular}

出所 : 各社『CSR 報告書』等 (2012 年度).

1）下線は平均より下回っている数值を示す.

表 2. 業種別 ISO26000 開示率

\begin{tabular}{|c|c|c|c|c|c|c|c|c|}
\hline 業種 指標 & 組織統治 & 人権 & 労働慣行 & 環境 & $\begin{array}{c}\text { 公正な } \\
\text { 事業慣行 }\end{array}$ & 消費者課題 & $\begin{array}{c}\text { ユミュニティ } \\
\text { への参画 }\end{array}$ & 企業数 \\
\hline 建築業・農林 & $\underline{66.7}$ & $\underline{58.3}$ & $\underline{66.7}$ & 100.0 & $\underline{80.0}$ & $\underline{66.7}$ & 100.0 & 5 \\
\hline 食料品・医薬品 & 100.0 & $\underline{77.5}$ & 96.0 & 100.0 & $\underline{80.0}$ & 91.4 & 100.0 & 6 \\
\hline 輸送用・精密機器 & 100.0 & 100.0 & 100.0 & 100.0 & 100.0 & 100.0 & 100.0 & 6 \\
\hline 卸売業・金融業 & 100.0 & 93.8 & 100.0 & 100.0 & 90.0 & 100.0 & 100.0 & 3 \\
\hline 証券・保険 & 100.0 & 93.8 & 100.0 & 100.0 & $\underline{80.0}$ & 92.9 & $\underline{85.7}$ & 3 \\
\hline 不動産・運輸業 & 100.0 & $\underline{75.0}$ & 100.0 & 100.0 & 100.0 & $\underline{85.7}$ & $\underline{85.7}$ & 2 \\
\hline 総合 (平均) & 92.9 & 79.5 & 91.4 & 100.0 & 84.3 & 87.8 & 96.9 & 25 \\
\hline 標準偏差 & 12.5 & 14.7 & 12.4 & 0.0 & 9.8 & 11.5 & 6.9 & - \\
\hline 変動係数 & 13.5 & 18.5 & 13.6 & 0.0 & 11.7 & 13.1 & 7.2 & - \\
\hline
\end{tabular}

出所 : 各社『CSR 報告書』等 (2012 年度).

1）下線は平均より下回っている数值を示す. 
していないことがある. 表2 のとおり，ISO26000で は，取り組むべき中核主題として 7 項目をあげてい る.「人権」では平均開示率が $79.5 \%$ と低く, 変動 係数が大きく業種間で開示の有無に格差がある. こ れは, GRI ガイドラインと同じ結果である.「組織統 治」「労働慣行」では平均開示率が約 $90 \%$ と高く, 変動係数も大きくなり, 業種間で開示の有無に格差 があるといえる。

第 3 に, 表 1 , 表 2 から GRI ガイドラインの平均 開示率が 59.7\%, ISO26000 の平均開示率が $89.0 \%$ と なり，ISO26000 の平均開示率が高い。これは，GRI ガイドラインの項目が ISO26000 の項目に比べて細 か寸ぎるのが原因であると考兄らる。 また，両者 の共通点として,「人権」の平均実施率が低く, 業種 間で開示の格差が大きいことがあげられる。

\section{(2) CSR 会計}

実際に調査企業が報告しているCSR 会計について 次の 3 点について検討する，すなわち，第 1 飞，調 査企業と CSR 会計の開示状況についてである. 調査 企業 505 社のらち 20 社 (4.0\%) が CSR 会計を報告 している。その内訳をみると，16社（80.0\%）が付 加価値型で，4 社 $(20.0 \%)$ が CSR 関連コスト型と なっている.

第 2 に, 付加価值型に打祆付加価値の分配先の 種類についてである.「社員・役員」「株主・少数株 主」「政府」は $100.0 \%$ である。それに対して，「社 会」や「環境」を分配先として認識・表示している 企業は少ない（各 68.8\%，50.0\%)。この浪かの分配 先として，「債権者」(87.5\%) がある.

第 3 に, 損益計算書と CSR 会計の関係についてで ある. CSR 会計情報の正確性・信頼性のためには, CSR 会計に打ける数值が損益計算書などの財務諸表 で確認できる必要がある，付加価值型では, 計算式 が記載されていることが多いので, 数值の確認をす ることができる。これに対して，CSR関連コスト型 では数值の確認はできない，付加価値型の例として JR 東日本の CSR 報告書では， CSR 会計だけでなく 略した形ではあるが損益計算書を示し，算出方法を 記載している。 これによって，ステークホルダーが CSR 会計に打ける数值の正確性を確認することがで きる. 付加価値型で報告をしているこの活かの企業 に扎いては，損益計算書が記載されている企業は少
ないが，算出方法が記載してあるため数值の正確性 を確認することができる.

以上のことをとりまとめると，一般企業が実施し ている CSR 会計では, 以下の 2 つの特徵があげられ る. 第 1 亿, 報告形式として付加価値型の報告が最 も多いことである。その理由として，2000 年から CSR 報告書等のガイドラインとして世界的に利用さ 孔ている GRI ガイドラインに準拠していること, CSR 会計の数值の確認ができること, が考光られ る. 第 2 に, 分配先に「社会」「環境」を含めている 企業があることである。

\section{4. 農業経営における CSR 会計 \\ (1) 事例に基づく CSR 会計の構築}

前節のとりまとめで述べた CSR 会計の 1 つ目の特 徵によって, 農業経営に打任るCSR 会計では, 付加 価値型を採用することにする。また，本節では，鳥 取県東部に立地する鳥取いなば農業協同組合（以下 JA 鳥取いなばという）管内の Y 生産組合を事例とし て検討するが, このCSR 会計の特徴として, 付加価 値型であることのほかに, 生産履歴を利用する点が ある、すなわち，JA鳥取いなばでは，全組合員に対 して生産履歴の記入を義務付けている. 生産履歴と は, 栽培農地・品目ごとに農薬・肥料の種類や使用 量, 使用時期を記載し, JA 鳥取いなばに出荷の際は 提出を義務付けているものである. 財務諸表や仕訳 帳では，農業経営全体としての農薬費・肥料費の使 用金額はわかるが，そ机だけでは，どの作物にどの ように使用したのか, つまり, 病害虫の発生が減少 したことによる影響なのか, それとも経営努力によ るものなのかを判断することができない，そこで， 生産履歷を用いることによって，これらのことを明 確に表示することができる，ところで，Y生産組合 の概要は次のと打りである. 1999 年設立, 2012 年 度は作付面積が 17.04 ha，米を中心に白ネギ，大豆 などを栽培している，売上高は，19,234.1千円であ る. 組合員が 12 名, 繁忙期のみ臨時パートを 4 人 $\sim 5$ 人雇用している.

生産履歴を用いたCSR 会計, すなわち, 表 3 の作 成方法は, 以下の通りである. 第 1 亿, 売上高を損 益計算書により計上する。 このとき，売上を仕訳帳 を用いて販売先ごとに分ける。すすなわち，JA などの 
表 3. 生産履歴を用いた CSR 会計

単位：千円

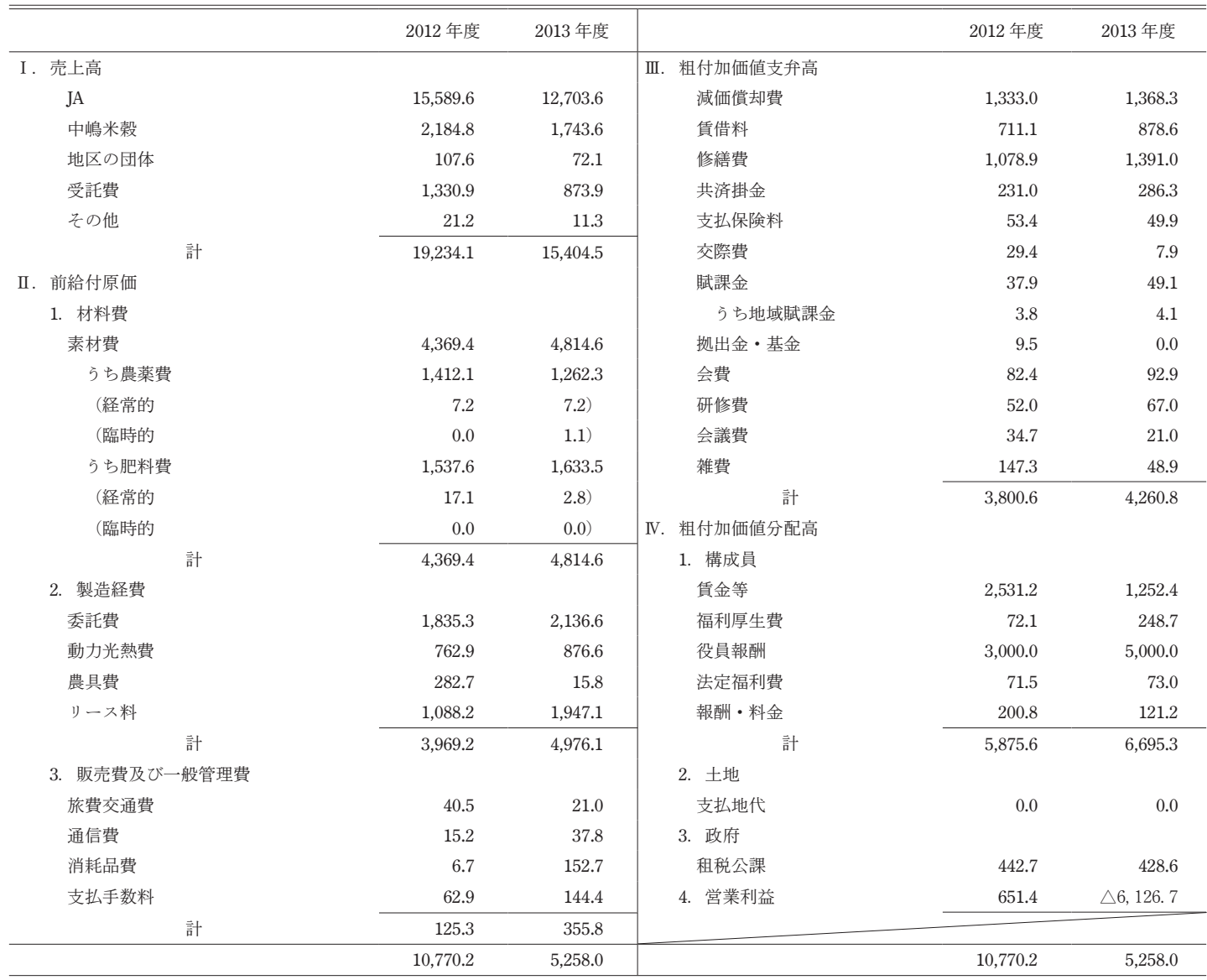

出所：農事組合法人 Y 生産組合『財務諸表』，仕訳帳，生産履歴（2012 年度， 2013 年度）

1）農薬費・肥料費欄の「経常的」「臨時的」はデータの関係により，「きぬむすめ」の $10 \mathrm{a}$ 当りのみを記載。

2）農薬費・肥料費に関しては 2014 年 7 月現在の価格を用いる.

3）数值は千円で四捨五入しているため, 合計額があわないことがある.

地域内への売上と地域外への売上を区分する.この ことにより，地域との関わりを明らかにすることが できる．第 2 に，製造原価報告書と損益計算書によ り，前給付原価に含まれる項目を計上する。 ここで, 「材料費」の「素材費」に含ま狆る「農薬費」と「肥 料費」を，生産履歴・栽培暦に基づいて経常的と臨 時的と分ける。このことにより，滅農薬・減肥料な ど，経営努力に取り組んでいることを示すことがで きる ${ }^{6}$. 第 3 に,「粗付加価值支弁高」に「人件費」 及び「租税公課」を除くすべての販売費および一般 管理費（損益計算書），製造経費（製造原価報告書） を計上する。ここでも，「賦課金」なぞも地域からの
ものについては, 別途記入する. 第 4 と,「粗付加価 值分配高」に構成員，土地，政府への適切な支払を 意味寸る「賃金等」「支払地代」「租税公課」を計 上する. 残額は，損益計算書上の営業利益と一致す る. この点に沶いて数值の確認が可能である.

\section{(2) CSRに関する分析}

CSR 会計（表 3） に基づく分析方法を検討する. ただし，分析指標をトリプルボトムラインの概念に 基づき社会・経済・環境の 3 つに分けると, 経済に ついては，従来の財務分析を利用することができる. したがって, 本研究では, 社会と環境についての分 析方法を検討する。第 1 に，地域貢献（社会貢献） 
を分析するために地域還元額 ${ }^{7}$, 地域還元率 8 を算出 する. 表 4 をみると, 地域還元額は 2013 年度は 2012 年度に比べて約 100 万円増加して打り，地域還元率 は約 16\%上昇している．この増加要因としては，役 員の数が 1 人増えたことによる役員報酬の増加があ げられる．第 2 に，CSR 会計作成方法の第 2 で計算 した「材料費」の「農薬費」，「肥料費」を「経常的」 と「臨時的」に区分した值を利用して，同じ作物で も栽培方法が異なる場合に沶ける，環境負荷の軽減 について検討する。表 5 より，同じ「ひとめぼれ」 を栽培しても地区が違らことにより，肥料費が大き く異なってくることがわかる. また，特別栽培米コ シヒカリはふつらのコシヒカリを栽培するよりも農 薬費は「臨時的」が少なく, 肥料費は「経常的」が 約 6,000 円多く負担していることがわかる. これが 特別栽培米の特徵といえる. 本研究では 2 力年度を 比較したが, 数年度について作物や栽培地区ごとに

表 4. 地域還元額と地域還元率

\begin{tabular}{l|rr}
\hline \hline \multicolumn{1}{c|}{ 項目 } & 2012 年度 & 2013 年度 \\
\hline 地域還元額（千円） & 7,367 & 8,389 \\
地域住民の雇用 & 2,531 & 1,252 \\
作業委託費 & 1,835 & 2,137 \\
役員報酬 & 3,000 & 5,000 \\
支払地代 & 0 & 0 \\
地域還元率 $(\%)$ & 38.3 & 54.5 \\
\hline
\end{tabular}

出所 : Y 生産組合『財務諸表』(2012 年度, 2013 年度). 1）地域還元額 $=$ 地域住民の雇用 + 作業委託費 + 役員報酬 地域還元率 $=$ 地域還元額 $\div$ 総売上高 $\times 100$

表 5. 栽培品目と農薬費・肥料費 (10 a 当り)

\begin{tabular}{|c|c|c|c|c|c|c|c|}
\hline \multirow{2}{*}{ 栽培品目 } & \multirow{2}{*}{ 費用 } & \multicolumn{2}{|c|}{2012 年度（円） } & \multicolumn{2}{|c|}{2013 年度（円） } & \multicolumn{2}{|c|}{ 栽培面積（a） } \\
\hline & & 経常的 & 臨時的 & 経常的 & 臨時的 & 2012 年度 & 2013 年度 \\
\hline \multirow{2}{*}{$\begin{array}{l}\text { ひとめぼれ } \\
\text { (T 地区) }\end{array}$} & 農薬費 & - & - & 6,530 & 4,850 & \multirow{2}{*}{701.5} & \multirow{2}{*}{712.1} \\
\hline & 肥料費 & - & - & 6,220 & 0 & & \\
\hline \multirow{2}{*}{ コシヒカリ } & 農薬費 & - & - & 6,530 & 4,850 & \multirow{2}{*}{299.0} & \multirow{2}{*}{299.0} \\
\hline & 肥料費 & - & - & 5,770 & 0 & & \\
\hline \multirow{2}{*}{ 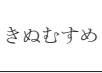 } & 農薬費 & 7,153 & 0 & 7,153 & 1,095 & \multirow{2}{*}{120.7} & \multirow{2}{*}{213.7} \\
\hline & 肥料費 & 17,100 & 0 & 2,770 & 0 & & \\
\hline \multirow{2}{*}{$\begin{array}{c}\text { ひとめぼれ } \\
\text { (Y 地区) }\end{array}$} & 農薬費 & - & - & 6,530 & 5,000 & \multirow{2}{*}{72.7} & \multirow{2}{*}{163.0} \\
\hline & 肥料費 & - & - & 7,270 & 0 & & \\
\hline \multirow{2}{*}{$\begin{array}{c}\text { 特栽米 } \\
\text { コシヒカリ }\end{array}$} & 農薬費 & - & - & 6,443 & 0 & \multirow{2}{*}{209.0} & \multirow{2}{*}{210.6} \\
\hline & 肥料費 & - & - & 11,791 & 0 & & \\
\hline
\end{tabular}

出所：農事組合法人 Y 生産組合 生産履歴 (2012 年度, 2013 年度).

1）「一」はデータがないところを意味する.
農薬費・肥料費を示すことによって，将来の栽培計 画を立てることが可能になる。

\section{5. おわりに}

本研究では, 農業経営に扣いて生産履歴を利用し た付加価值型の CSR 会計を構築することができた. また，その CSR 会計に基づく分析方法を提示するこ とができた．今後の課題として，地域還元額に，地 元からの仕入と賦課金を計上するかどらか, また， 香川他（2008）のように自己資本，自作地について 付加価値の分配を行らかどらか検討することがある.

注

1 一般企業に扮ける CSR 活動, CSR 会計の特徵に関しては, 農業会計研究会 (2013 年 1 月 12 日, 京都大学) で報告済み。

2 企業が CSR 活動を報告する文書として，「CSR 報告書」以外 に「社会・環境報告書」や「サステナビリティレポート」な ぞ様々な名前で報告しているため，これらをまとめて「CSR 報告書等」としている。

3「エコほっとライン」とは, CSR 報告書等を掲載・発送代行 サービスを行っている webページである.

${ }^{4}$ ISO (国際標準化機構) のSR（社会的責任）に関する基準で あり，今までのような認証システムではなく，ガイドライン とされている。

${ }^{5}$ GRI ガイドラインは初版が 2000 年に発行されているのに対 し. ISO26000は 2010 年に発行されていることが，原因と考 えられる.

6 本事例では, データの都合上一部のみ記載している.

7 四方（2012）を参考にして算出する.

8 古塚（2013）を参考にして算出する.

\section{引用文献}

倍 和博 (2008)『CSR 会計への展望』森山書店.

古塚秀夫（2013）「大山乳業農協による酪農振興と地域活性化 への道」高橋信正編著『「農」の付加価值を高める 六次 産業化の実践』筑波書房, 225-234.

香川文庸・小田滋晃（2008）「農業経営の社会的責任とアカウ ンタビリティ」『農林業問題研究』44(3), 410-424.

佐々木市夫（2008）「農業経営に抢ける社会的責任と新会計」 『農林業問題研究』44(3), 405-409.

四方康行（2012）「農業法人経営の会計と経営分析」稲本志良 編集代表『農業経営発展の会計学一現代, 戦前, 海外の経 営発展一』昭和堂, 21-45. 